\title{
Impact of the Ownership Structure on the Financial Performance of Banks: Comparative Study between Conventional and Islamic Banks
}

\author{
Achraf Haddad \\ Doctor in Financial and Accounting Methods \\ Researcher at a Laboratory of Finance, Governance, and Accounting \\ Faculty of Economics and Management of Sfax, Tunisia \\ University of Sfax, Tunisia \\ E-mail:achraf.haddad2015@gmail.com \\ Anis El Ammari \\ Associate Professor of Accounting and Finance \\ Department Head of Accounting, and Finance \\ Faculty of Economics and Management of Mahdia, Tunisia \\ University of Monastir, Tunisia \\ E-mail:ammari_anis1@yahoo.fr \\ Abdelfattah Bouri \\ Professor of Finance \\ Director of Finance, Governance, and Accounting Laboratory \\ Faculty of Economics and Management of Sfax, Tunisia \\ University of Sfax, Tunisia \\ E-mail:bouriabdelf@gmail.com
}

\begin{abstract}
According to the literature of corporate governance, ownership structure is advanced as a non-dissociable mechanism of control intended to follow the stakeholders and especially used by shareholders to monitor the conflicts of interest and the opportunistic behavior of managers. Several previous studies have focused on the impact of ownership structure on financial performance separately in conventional or in Islamic banks. However, the comparative studies between these two impacts are non-existent. In this research, we compared the impacts of this governance mechanism on the financial performance in the two types of banks by using the Ordinary Least Squares method. Data relating to financial performance and ownership structure of banks come from I6 countries. Two samples were collected: the first one included 63 conventional banks, whereas the second one integrated 63 Islamic banks whose data are available over the period (2010-2018). Panel results showed that the partial effect of each determinant of ownership structure on each measure of financial performance varied from one bank type to another and from one performance measure to another. Besides, the reconciliation of similar models revealed many differences between the same impacts' signs. Therefore, we concluded that in both banks' types the ownership structure has a positive impact on financial performance. While the negative part of the same impact is less significant in Islamic banks.
\end{abstract}

Keywords: Conventional Banks, Islamic Banks, Ownership Structure, Corporate Governance, Comparative Study.

JEL Classification: F33, G20, G2I, G24, G30.

\section{Introduction}

The OS ${ }^{I}$ has been used in the literature as an internal mechanism of governance (Al-Rassas \& Kamardin, 2016; Aminul et al., 2018). It is an effective tool for monitoring relationships between shareholders and managers through incentive and cost control (Gebba \& Aboelmaged, 2016). The OS dispersal plays an important role in reducing agency problems. Numerous studies in the area of governance analyzed the structural impact of ownership as an implicit control mechanism that can affect the strategic

I Ownership Structure 
decisions of banks and directly affects their FP (Ozer \& Yamak, 2000). In this context, Iannotta et al. (2007) defined the OS as the distribution of voting rights between the different shareholders. It can be seen through two main dimensions: the ownership concentration degree and the owners' nature.

The link between OS and performance has been subject to an endless debate in the literature of corporate and market finance. Several studies have reported the existence of a very influential OS effect on the FP² (Ozer \& Yamak, 2000; Iannotta et al., 2007; Gurbuz et al., 2010). This relationship's interpretation depends on the theoretical approach foundations and the vision of the old research currents compared to the adopted current. According to agency theory, the profitability of a bank could be related to its OS (Jensen \& Meckling, 1976). Indeed, Shleifer \& Vishny (I997) have argued that concentration in ownership of capital can have an impact on the corporate governance quality, mainly from the majority of shareholders.

It is worth noting that other empirical results have focused on the ownership concentration effect on risk-taking and FP, but they have not found any systematic influence of OS on accounting performance (Demsetz \& Lehn, I985; Bozec \& Bozec, 2007). At the international level, Lang \& So (2002) analyzed the impact of OS on the performance of listed banks. They concluded that the OS has no impact on their profitability and their accounting results. Similarly, Tandelilin et al. (2007) analyzed the impact of Indonesian banks' governance practices on their FP. He concluded that the association between the governance of Indonesian banks and the FP is sensitive for the different types of banking ownership while particularly agreeing that the relationship between the Indonesian banks' governance and risk management is also sensitive to the type of banking ownership. As a result, the OS has no significant effect on bank governance.

It seems through the literature review that the majority of previous studies have investigated only the impact of OS on firms' FP or they have studied the same impact on the performance of $\mathrm{CBs}^{3}$. Nevertheless, no studies have verified this relationship in the framework of $\mathrm{IBs}^{4}$ or a comparative study between conventional and Islamic banks. For this reason, we took advantage of this gap; by the way, we think that our research is the first that deals with this problem after the Subprime crisis. Precisely, our predefined research questions consist of comparing the relationship between OS for each banking model and their FP.

The first purpose of our explanatory research is to study the relationship between a set of measures related to FP and some valuation variables of the OS quality to extract the signs of correlations. Second, we aim to show the OS impacts on the profitability, the efficiency, the liquidity, and the solvency of each bank type to compare and choose the most efficient ownership governance approach which is more valuable for all financial institutions of all types.

Our methodological contribution is that the banks selected to form the two samples are all large and listed in different stock markets around the world. Restriction of size has required the elimination of small banks that are generally unlisted. This combination systematically reduces the effect of categorical homogeneity, of banks' differences, of banks' structures, of banks' particularities, of the contingency factors and the specific governance systems for each sample. The results of our research can be a valuable source of knowledge for investors, policymakers, funders, economic agents and regulators, especially in the financial services sector and in the development of financial objectives and planning strategic plans for controlling the OS.

The rest of the paper is organized as follows. Section 2 outlines the literature review and hypotheses development of the OS determinants' impacts on FP. In section 3, we exposed the control variables' effects on FP of conventional and Islamic banks. Section 4 specifies the models applied, the description of the data and the empirical results. The concluding remarks are in Section 5.

\section{Literature Review: OS Determinants}

According to agency theory, the causal relationship between OS and FP can be symbolized by two components: the capital concentration and the shareholders' type (Gebba \& Aboelmaged, 2016). These reasons led us to choose the CEO shareholding and the shareholding of the board's chairman as a criterion for measuring the OS, unlike the majority of the previous studies that used the ownership concentration. However, this correlation depends on other factors, mainly related to the study context, the financial institutions' type part of the study and their characteristics, including also the convergence or the divergence between shareholders' interests and executives.

\section{I CEO Shareholding}

In this topic, previous research has advocated the existence of a multidimensional relationship between managers holding securities in a banks' capital and its FP (Ozer \& Yamak, 2000). This relationship is not independent in it but is in line with the interests of other stakeholders, its involvement in the bank management, their holdings of participations, and its unseen behavior. The relationship may influence (directly / indirectly) or (totally / partially) either the non-compliance with the contract

\footnotetext{
${ }^{2}$ Financial Performance

${ }^{3}$ Conventional Banks

${ }^{4}$ Islamic Banks
} 
standards of one party or another or the change in behavior of one party towards the other parties. These disorders are concretized either by the divergence of the CEO interests and the other owners' interests or by the rooting of the leaders.

Most previous studies found a linear relationship between the CEO ownership, as a governance mechanism, and the FP. Some studies have predicted that in most developing countries the OS is highly concentrated among a very limited number of shareholders. Majority owners of capital have tried to impose their financial interests to the detriment of the minority shareholders' interests, which has developed agency problems and has encouraged the spread of opportunistic behavior (Carcello et al., 20I I). In other words, the concept of good governance does not necessarily need to be linked to the shareholders' interests since they can appoint close members to the board of directors (Beltratti \& Stulz, 2012).

Similarly, Dhillon \& Rossetto (2015) pointed out that the private benefits behind CEO ownership have opposite effects on his wishes to share private information with the board of directors, which can influence the CEO's independence and limit his power. To encourage the CEO to communicate financial information to the board of directors, the institution must optimally perform a revaluation but with low monitoring intensity when the CEO ownership is weak or when the CEO takes advantage of many privileges of private benefits.

Indeed, Iqbal et al. (2015) studied the relationship between the quality of big banks' governance and their systemic risk between $2005 \& 2010$. They used a sample of US banks to test whether the governance strength has an impact on the crosssectional variation of systemic risk. They found that banks with strong shareholder and board-based governance structures are associated with high levels of systemic risk.

Also, Fahlenbrach \& Stulz (20II) founded that during the period of the Subprime crisis, when the incentives of banks' managers are constantly aligned with the interests of its shareholders, banks are found to be performing better. However, in the same unfavorable environment, banks whose CEOs are favored with higher option compensations do not perform well compared to their counterparts who offered fewer options.

Besides, Thu et al. (2016) studied the impact of some mechanisms of banking governance on the performance of Vietnamese commercial banks over the period (2008-20I4). They revealed that banks with high foreign ownership ratios have low profitability and vice versa. This result is due to the participation of foreign ownership which has taken a long time to integrate with the local market. On the contrary, internal ownership is positively correlated with bank performance.

Moreover, Onali et al. (2016) studied the power of the CEO, as a mechanism of governance, on the dividend policy of the listed European banks between the years 2005 and 2013. To measure the CEO power, they used three indicators that are shareholding, term of office, and forced change of CEO. The results showed that CEO power has harmed the FP and dividend payout ratios. They relegated their finding to the old rooted directors since they have no incentive to distribute the dividends to the minority shareholders.

After an argumentative exposition of the literature, we decided to propose the most appropriate hypothesis:

\section{Hypothesis I: CEO shareholding has a negative impact on the FP of conventional and Islamic banks.}

\subsection{Board's Chairman Shareholding}

The relationship between the board's chairman shareholding and the banks' FP has been intensively discussed in both theoretical and empirical literature. This mechanism is classified into the design of the internal mechanisms of governance. As already noted in the literature, Needles et al. (2012) analyzed the impact of governance mechanisms on credit scores performed by firms. They demonstrated a negative association between the holders' number of share blocks and the CEO power. However, they also revealed a positive association between the holders of share blocks and the control constraints, board independence and expertise, and the relevance of the benefits.

In accordance with what has been promulgated in the literature about agency theory, the board's chairman shareholding in the capital of the bank affects not only its independence but also, the independence of its decisions, that probably results more from agency problems than from to the situation where the board's chairman is not an owner. Whereas, that does not preclude the existence of some research summing up the findings in an assertion provides that the board's chairman involvement in a bank's capital decreases interest conflicts with other stakeholders. Holding the shares by the board's chairman creates material ambitions and financial dissatisfaction with the CEO and other directors. In this sense, Carter \& Stover (I99I) founded that executive's and directors' ownership is another mechanism of governance that aligns the interests of board directors with the interests of shareholders of the bank board.

In addition, Kallamu (2016) analyzed the impact of the presence of independent shareholder directors on the performance of Malaysian banks between 2007 and 20II. He revealed that the Malaysian central bank is aiming to restructure the composition of the boards of directors so that they contained independent directors, as they help reduce agency problems. In other words, the presence of non-shareholder independent directors may not be appropriate for banks with a high level of ownership. For this reason, in banks where directors hold shares, the presence of independent members on the board will improve the FP of banks. 
Moreover, Rowe et al. (20II) analyzed the impact of board characteristics on the performance of Chinese banks, they revealed that ownership of directors has a significantly positive impact on bank performance. Also, the percentage of executive directors negatively affects banks' FP.

Based on previous results, we have tested the following hypothesis:

Hypothesis 2: The shareholding of the board's chairman has a positive impact on the FP of conventional and Islamic banks.

\section{Control Variables May Have an Impact on the Financial Performance of Conventional and Islamic Banks 3.I Bank Type}

Few studies in the literature have highlighted the importance of the typological distinction between financial institutions in the governance theory. Comparative studies establishing a causal link between the governance mechanisms' quality and the banks' FP are almost non-existent. The differentiation between the categories, groups or types of banks depends on the purpose of the study and the details of the discussed topic. In this sense, Macey \& O'Hara (2003) argued that the consideration of the peculiarities of any type of banks requires a thorough review of the attention given to specific governance and a renewal of sequencing efforts and mechanisms, because bank officials play a crucial role in the economy, especially for depositors.

Indeed, deep research on the correlation between banking classes and banking performance has focused on other typological divisions. In other studies, some researchers in finance have advanced a different investigation of this concept in a reading assimilated to other contexts, or they have established a conceptual presentation keeping the same context, but they have changed simply the theme. The initiators of this stream discussed the distinction between banks based on the separation between the typology "Origin of Institutional Ownership" and the typology "Regional Integration of Banks". In this line of research, Kim \& Rasiah (2010) compared the governance impact on the performance of two types of banking ownership in Malaysia before, during, and after the Asian financial crisis. They have shown that there is generally a positive and significant correlation between banking governance and FP of Malaysian banks. Also, before the crisis, foreign-owned banks had better governance quality and they earned more than private domestic banks. However, after the crisis, the findings showed the opposite, private domestic banks recorded better governance quality and a higher profits level.

Other researchers have preferred the establishment of dissimilar reference classes. In this case, the distinction is made between private and public banks or between listed and unlisted banks. At this point, Cornett et al. (2009) tested the difference between the impact of privatization and state participation on the performance of commercial banks in 16 countries from the Far East between 1989 \& 2004. The study examined how the type of banks' shareholding can affect its performance. They argued that the performance of public and private banks sharply deteriorated over the trial period. In countries where government participation in the banking sector is very important, banks have shown lower performance. Nevertheless, public banks have generated a lower level of profitability and efficiency than private banks. Besides, they found that private banks were more profitable, had more capital base, and had lower credit risk compared to their counterparts before and during the Asian crisis. Faced with this situation, four years after the financial crisis, Cornett et al. (2009) detected that the reduction in the cash flow, the capital base, and the loans' quality granted by public banks was remarkable and clearly higher than private banks. After the crisis, public banks cut off with private banks through cash flow, core capital, and non-performing loans. As a result, public banks recovered their performance to levels similar to those of private banks during the post-crisis period.

Although there is no official standard or uniform segmentation, we have selected a specific distinction based on a purely practical classification. The border between these various types of institutions is relatively small based on a separation between the core business and the services offered by each category of banks. It is a distinction between commercial, business, and universal banks.

From the previous literature about this variable, we formulated the hypothesis as follows:

\section{Hypothesis 3: The banks' type has a positive impact on the FP of conventional and Islamic banks.}

\subsection{Bank Age}

Since the Islamic banking system is very recent, its conventional counterparts are concretely advancing practically. The majority of IBs are more recent than the conventional banks, although Islamic finance appeared before the launch of the conventional banking model in the world. IBs have to go through a number of challenges to develop their products in order to achieve significant performance in the banking market in competition with their conventional counterparts (Chong \& Liu, 2009; Badreldin, 2009). Also, the operating roots of CBs have gained greater experience in the mechanics of the financial markets and a greater share in the financial sector (Samad, 2004a).

Over the years, the Islamic financial model has expanded and has been on a gradual upward trend. Success has spread throughout the world and not only in the Muslim world. Currently, IBs are located in Asia, America, Europe, the Middle East, 
and Africa. Countries accepting the practice of Islamic finance in its territories are in a number of fifty-seven countries ${ }^{5}$. Besides, Bilal \& Abbas (2015) reported that Bahrain and Malaysia are in the process of becoming regional hubs for Islamic financial service providers.

Moreover, Shamsher et al. (2008) compared the efficiency of costs and profits of two banks groups, a CBs sample and another of IBs. Each group is divided into two classes of banks, old and new. Data were collected based on age, size, and region. Age was measured by the starting date. They argue that the newer banks had better cost efficiency and profit efficiency similar to that of the old banks. This could be because the new banks have learned from the experiences of the old banks. Furthermore, the attempts of the new banks aimed at offering the customers of the old CBs higher interest rates than the rates offered by the old ones of the same group and to discuss with the customers of the IBs of the same class the percentages of higher profits. Even more, Alharthi (2016) found the same results in the MENA region; the new Islamic and conventional banks work better than the older banks.

Similarly, Jemric \& Vujcic (2002) analyzed the effectiveness of a CBs sample in Croatia between I995 and 2000. The results revealed that the new Croatian banks are more efficient than the old ones. The problem of old banks was mainly due to the non-performing portfolio containing either non-efficient or non-profitable products. In addition, the inefficiency of the old banks compared to the new banks' amounts to the excess of the employees' number and the assets costs fixed too high. Moreover, Kraft \& Tirtiroglu (1998) revealed that the conventional Croatian banks recently established in the banking market are less efficient than the old ones, regardless of whether they are private or state-owned; but they have offered a higher profitability than that generated by the old banks.

From the literature review already stated, we have proposed the following hypothesis:

Hypothesis 4: The banks' age has a negative impact on the FP of conventional and Islamic banks.

\subsection{Bank Size}

Earlier studies have also shown that size is a determinant of profitability and leverage in banks (Caglayan \& Sak, 2010 and Gropp \& Heider, 2010). This variable is always defined by the logarithm of the total assets of a bank (Flamini et al., 2009). Moreover, the size has generally been used to capture the ability of banks to adopt and to exploit economies of scale in their transactions and their tendency to maximize profits. The goal of profit maximization is found at some level to seek an optimal bank size.

Likewise, other studies have demonstrated that there is a positive and significant correlation between bank size and FP (Shamsher et al., 2008; Sufian \& Noor Mohamad Noor, 2012; \& Fahad, 2014). These authors concluded that as banks expand, so does their ability to improve profitability. Even more, Grigorian \& Manole (2002) carried out a study on a set of countries that were restructuring their banking sectors. They estimated the indicators' effect on the effectiveness of commercial banks over the period (I995-1998). The sample consisted of banks from I7 countries. They discovered that large banks and wellcapitalized banks are likely to generate better overall banking efficiency from their operations.

By the same token, Manthos \& Nikolaos (2009) analyzed the effect of macroeconomic banking determinants on the efficiency of European banks. The determinants chosen to clarify the effects on efficiency are the bank size, the sectoral concentration and the degree of economic investment. They found that the bank size and the external investment environment act positively on the banks' efficiency. It is worth noting that, the concentration of the sector has a statistically negative effect on efficiency. Similarly, Saeed (20I4) surveyed the impact of the bank's specific variables, sector variables and macroeconomic factors on the profitability of 73 UK commercial banks during the period (2006-2012). From the regression analysis, he founded that bank size is positively related to ROA and ROE. In another context, Hussein \& Charif (20II) assessed the impact of bank size on the performance of commercial banks in the UAE over the period (1996-2005). They worked on data from I5 major banks and 23 small banks. As a result, they confirmed that large banks operate more efficiently than smaller banks.

Moreover, Bhagat \& Black (2002) revealed the priority of financial institutions to add external directors to their boards of directors following a decline in FP. This result is explained by the opacity of the financial transactions of the assets and the complication of the banking operations. The resolution of this problem requires more vigilance, precaution, and solicitude on the part of the leaders and more control, occupation, and verification exercised by the internal and external mechanisms of governance whose role is to reduce moral hazard behavior among stakeholders. Theoretically, the size of the total assets must have a positive impact on the banks' efficiency. But that does not prevent the existence of optimal size in the big banks; they always have the possibility of maximizing their commercial powers. After all, small banks with a maximum commercial threshold

\footnotetext{
${ }^{5}$ Algeria, Tunisia, Egypt, Morocco, Switzerland, Ethiopia, Mauritania, Nigeria, Turkey, Botswana, South Africa, United Arab Emirates, Cameroon, Syria, France, Chad, Germany, United Kingdom, Kenya, Saudi Arabia, Oman, Pakistan, Libya, Russia, Gambia, Indonesia, Iran, Bangladesh, Ghana, Sudan, Denmark, Afghanistan, Brunei, Tanzania, Kazakhstan, Bahrain, India, Guinea, Liberia, China, Senegal, Jordan, Iraq, Malaysia, Mauritius, Luxembourg, Lebanon, Trinidad and Tobago, Qatar, Canada, Kuwait, Sri Lanka, Azerbaijan, Palestine, Thailand, Yemen, and the United States.
} 
cannot exceed large banks because of resource, capacity and competition constraints (Rashwan \& Ehab, 20I6). Besides, in his comparative study between conventional and Islamic banks in the MENA region, Alharthi (2016) reported that CBs with a larger size perform better than smaller commercial banks. Indeed, he stated that the benefits of the loans have improved efficiency significantly. About IBs, the author also concluded that large IBs have proven more effective than smaller ones.

This is why our hypothesis took the following formulation:

\section{Hypothesis 5: The banks' size has a positive impact on the FP of conventional and Islamic banks}

\subsection{Inflation}

The annual inflation rate is the overall percentage increase in the Consumer Price Index for all goods and services. The impact of inflation on bank performance has been widely discussed in the finance literature as well as in the governance literature. Inflation is often used by many previous studies to assess the variation, evolution, and change in economic contingency factors over time (Rashwan \& Ehab, 2016; Batir et al. 2017). In particular, inflation is a determinant of banks' FP because of its influence on depositors' funds, which are the financial resources of banks.

Several previous studies have found a positive association between inflation and banks' FP. The revenues' cost as a measure of profitability of IBs as well as CBs is not influenced by changes in the rate of inflation (Gul et al. 20II and Fahad, 2014). They thought that the increase in the inflation rate causes a rise in the valuation of the bank without affecting the demand for credit, therefore, inflation will not decrease commercial activities and it will have no negative effect on the banks' performance. The growth of the inflation rate is always associated with high-interest rates on loans, so banks will be more likely to maximize their income. In this sense, Gul et al. (201 I) conducted a panel study in Pakistan to examine the relationship of bank-specific characteristics and macroeconomic indicators on banks' profitability over 5 years (2005-2009). Therefore, they founded that inflation has a positive impact on all measures of profitability.

Although inflation is a necessary macro-economic measure to evaluate the FP of banks, Rashwan \& Ehab (2016) have designed a comparative study aimed at assessing the performance between conventional and Islamic banks in several countries through six efficiency and cost-effectiveness indicators. They collected empirical data from I2 countries during the period (2009-2014). In this framework, inflation has been used as a macroeconomic factor that can influence the efficiency of costs, revenues, and bank profits. The results discerned the existence of a non-significant impact of inflation on non-interest bank charges and the net interest margin of IBs. Otherwise, inflation significantly altered non-interest expenses and the net interest margin of CBs. This impact contributed to the slowdown of the growth of non-interest expenses and the stimulation of the net interest margin of CBs once the inflation rate rises. In terms of operating revenues, the results showed that inflation had a positive and significant effect on income in both types of banks. Nevertheless, inflation has no significant impact on the profitability of the assets and equity of Islamic and conventional banks. On the same theme, Alharthi (2016) has indicated that inflation influences the effectiveness of Islamic and conventional banks in a negative and significant way, while it has significantly improved the efficiency of two types of banks. For these reasons, we have seen that the most appropriate hypothesis is the following:

\section{Hypothesis 6: Inflation has a positive impact on the FP of conventional and Islamic banks.}

\section{Empirical Method: Discrimination between the Ownership Structure Impact on the Financial Performance of Conventional and Islamic Banks \\ 4.I Methodological Aspects}

The methodology applied in our exploratory study is a demonstrative comparison by resorting to modeling. The research plan to be followed to answer the questions already mentioned began with the clarification of the data sources, then we quoted the variables to be modeled, finally, we exposed our objective models.

\section{I.I Data Collection}

The choice of banks is limited to countries whose banking systems incorporate both Islamic and conventional banks over the period (2010-2018). Two populations are made up of I,788 conventional financial institutions and 467 Islamic financial institutions. The countries part of our study are Egypt, Bangladesh, Indonesia, Pakistan, Malaysia, Turkey, United Kingdom, Bahrain, Jordan, Kuwait, Oman, Qatar, Saudi Arabia, United Arab Emirates, South Africa, and Sri Lanka. However, we have excluded all specific financial institutions subject to particular regulations. The tested samples include only purely conventional or Islamic banks. In addition, due to difficulties in the collection of information on FP and OS, we excluded banks marked by some missing observations, variables or data. We also removed the multi-type mutated banks (Islamic-conventional window banks and conventional-Islamic window banks). These three conditions led us to eliminate I,725 conventional financial institutions and 404 Islamic financial institutions. Subsequently, we have reduced the banks' number remaining for each bank 
type based on some qualitative and quantitative filtering criteria (samples equality, activity type, similarity of origin country, bank width), each CB has its Islamic equivalence in terms of capital and size taken from the same country. This restriction reduced the size of our samples to 63 banks each. Finally, after several elimination and deletion steps, we obtained two pairs of equal samples $(\mathrm{nI}=\mathrm{n} 2)$.

\section{I.2 The Measurement of the Variables to Be Tested}

\section{A. Endogenous Variables}

Table (I) shows the parameters we worked on, the symbols and the relative reports: profitability, efficiency, liquidity and solvency.

Table I. Description of variables to explain

\begin{tabular}{llll}
\hline FP measurement & Rating for CB & Rating for IB & Measurement \\
\hline Profitability ratio & Rtc & Rti & Marginal Profit / Total Revenues \\
\hline Liquidity ratio & Ltc & Lti & Net Loans / Total Assets \\
\hline Efficiency ratio & Etc & Eti & $\begin{array}{l}\text { Operating Income / Average } \\
\text { Total Assets }\end{array}$ \\
\hline Solvency ratio & Stc & Sti & Total Loans / Total Deposits \\
\hline
\end{tabular}

\section{B. Exogenous Variables}

The predominantly independent variables have been described in Table (2) as follows:

Table 2. Description of the OS explanatory variables.

\begin{tabular}{|c|c|c|}
\hline Rating for $\mathrm{CB}$ & Rating for IB & Measurement \\
\hline $\begin{array}{l}\text { CB's CEO Shareholding } \\
\text { (ACDIRc) }\end{array}$ & $\begin{array}{l}\text { IB's CEO Shareholding } \\
\text { (ACDIRi) }\end{array}$ & $\begin{array}{l}\text { Binary variable: } \\
\text { I: if the director holds shares in the capital of the } \\
\text { bank } \\
\text { 0: if not. }\end{array}$ \\
\hline $\begin{array}{l}\text { Board's chairman } \\
\text { Shareholding of the CB } \\
\text { (ACDCAc) }\end{array}$ & $\begin{array}{l}\text { Board's chairman Shareholding } \\
\text { of the IB } \\
\text { (ACDCAi) }\end{array}$ & $\begin{array}{l}\text { Binary variable: } \\
\text { I: if the board's chairman holds shares in the capital of } \\
\text { the bank } \\
\text { O: if not. }\end{array}$ \\
\hline
\end{tabular}

C. Measurements of control variables

Table (3) displays the list of control variables and their measures.

Table 3. Description of control variables.

\begin{tabular}{|c|c|c|c|}
\hline Control variable & $\begin{array}{l}\text { Rating } \\
\text { for } C B\end{array}$ & $\begin{array}{l}\text { Rating } \\
\text { for IB }\end{array}$ & Measurement \\
\hline Bank Type & TYc & TYi & $\begin{array}{l}\text { A qualitative variable takes } 3 \text { forms: } \\
\mathrm{I}: \text { if the bank is a commercial bank } \\
2: \text { if the bank is an investment bank } \\
3: \text { if the bank is a universal bank }\end{array}$ \\
\hline Bank Age & AGc & AGi & Age of conventional / Islamic bank for each year \\
\hline Bank Size & TAc & TAi & $\begin{array}{l}\text { Logarithm of book value of total assets of conventional / } \\
\text { Islamic bank at the end of each year }\end{array}$ \\
\hline Inflation & $\mathrm{INFC}$ & $\mathrm{INFi}$ & $\begin{array}{l}\text { The rate of inflation in the country of origin of the } \\
\text { conventional / Islamic bank object of study }\end{array}$ \\
\hline
\end{tabular}

4.I.3 Presentation of Models to Estimate

Before proceeding to the estimations, we present the typical models to reassess several times the FP and each time the dependent variable will be changed according to the FP measures and the bank type. 
Conventional models of multiple regressions are of the following form:

Model I: Association between CBs' profitability and OS:

$$
\text { LnRtc }=\alpha_{0}+\alpha_{1} \text { ACDIRc }+\alpha_{2} \text { ACDCAc }+\alpha_{3} \text { TYc }+\alpha_{4} \operatorname{LnAGc}+\alpha_{5} \operatorname{LnTAc}+\alpha_{6} \operatorname{LnINFc}+\varepsilon_{t}
$$

Model 2: Association between CBs' efficiency and OS:

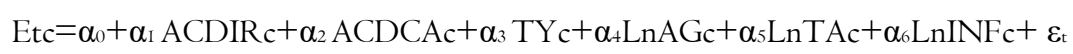

Model 3: Association between CBs' liquidity and OS:

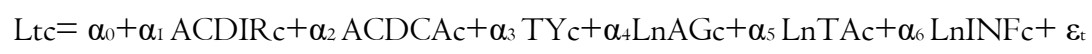

Model 4: Association between CBs' solvency and OS:

$$
\mathrm{LnStc}=\alpha_{0}+\alpha_{\mathrm{I}} \text { ACDIRc }+\alpha_{2} \mathrm{ACDCAc}+\alpha_{3} \mathrm{TYc}_{\mathrm{c}}+\alpha_{4} \operatorname{LnAGc}+\alpha_{5} \operatorname{LnTAc}+\alpha_{6} \operatorname{LnINFc}+\varepsilon_{\mathrm{t}}
$$

Islamic models of multiple regressions are of the following form:

Model 5: Association between IBs' profitability and OS:

$$
\mathrm{LnRti}=\beta_{0}+\beta_{1} \text { ACDIRi }+\beta_{2} \text { ACDCAi }+\beta_{3} \mathrm{TY}_{i}+\beta_{4} \mathrm{LnAGi}+\beta_{5} \mathrm{LnTAi}+\beta_{6} \mathrm{LnINFi}+\varepsilon_{\mathrm{t}}
$$

Model 6: Association between IBs' efficiency and OS:

$$
\mathrm{Eti}=\beta_{0}+\beta_{\mathrm{I}} \text { ACDIRi }+\beta_{2} \text { ACDCAi }+\beta_{3} \mathrm{TY}_{i}+\beta_{4} \mathrm{LnAGi}+\beta_{5} \mathrm{LnTAi}+\beta_{6} \mathrm{LnINFi}+\varepsilon_{\mathrm{t}}
$$

Model 7: Association between IBs' liquidity and OS:

$$
\mathrm{Lti}=\beta_{0}+\beta_{\mathrm{I}} \mathrm{ACDIRi}+\beta_{2} \mathrm{ACDCAi}+\beta_{3} \mathrm{TYi}+\beta_{4} \mathrm{LnAGi}+\beta_{5} \mathrm{LnTAi}+\beta_{6} \mathrm{LnINFi}+\varepsilon_{\mathrm{t}}
$$

Model 8: Association between IBs' solvency and OS:

$$
\mathrm{LnSti}=\beta_{0}+\beta_{\mathrm{I}} \mathrm{ACDIRi}+\beta_{2} \mathrm{ACDCAi}+\beta_{3} \mathrm{TY} i+\beta_{4} \mathrm{LnAGi}+\beta_{5} \mathrm{LnTAi}+\beta_{6} \mathrm{LnINFi}+\varepsilon_{\mathrm{t}}
$$

\subsection{Interpretation of the Comparative Results of the Ownership Structure Determinants on the Financial Performance} Measures of the Conventional and Islamic Banks

\subsection{Inter-Models and Inter-Banks Analysis}

Before judging the impacts of the OS quality, we should estimate the separate impacts provided by the OS determinants and the effects generated by the other control variables on the FP measures. To do this, we have established multiple linear models. So far, we have checked the significant variables that explain the quality of the ownership in each model. In the next step, we have established a comparative study between the same impacts of similar models.

\begin{tabular}{|c|c|c|c|c|c|c|c|}
\hline LnRtc & Coefficient & Std. Err. & $\mathrm{Z}$ & $\mathrm{P}>|\mathrm{z}|$ & \multicolumn{2}{|c|}{$[95 \%$ Conf. Interval $]$} & Decision \\
\hline ACDIRc & 0.4755846 & 0.0525308 & 9.05 & 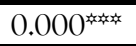 & $0.372626 \mathrm{I}$ & $0.578543 \mathrm{I}$ & HI rejected \\
\hline ACDCAc & 0.3976352 & $0.09987 \mathrm{I} 4$ & 3.98 & 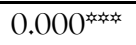 & 0.2018907 & 0.5933796 & H2 accepted \\
\hline TYc & 0.119113 & 0.0423303 & $2.8 \mathrm{I}$ & $0.005^{\text {紧 }}$ & 0.0361472 & 0.2020789 & H3 accepted \\
\hline LnAGc & 0.1621196 & 0.0454817 & 3.56 & 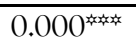 & 0.072977 & 0.2512622 & H4 rejected \\
\hline LnTAc & -0.0493477 & 0.0979862 & -0.50 & 0.615 & -0.2413972 & 0.1427018 & H5 rejected \\
\hline LnINFc & -0.2231928 & $0.023825 \mathrm{I}$ & -9.37 & 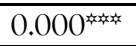 & $-0.269889 \mathrm{I}$ & -0.1764965 & H6 rejected \\
\hline Constant & 2.120484 & $0.33973 \mathrm{I} 4$ & 6.24 & 0.000 & $\mathrm{I} .454622$ & 2.786345 & - \\
\hline
\end{tabular}

A. Impacts of the ownership structure quality on the profitability of conventional and Islamic banks Based on the Table (4), the profitability model's coefficients related to the CBs saw two conclusions. Concerning ACDIRc, ACDCAc, TYc, and LnAGc, they have had positive and significant effects on the CBs' profitability at the I\% level. Nevertheless, LnINFc significantly affected the CBs' profitability at a rate of I\%. As expected, from the Table below, we confirmed hypotheses $n^{\circ} 2$ and $n^{\circ} 3$. By deduction, the second illustration allowed us to explicitly reject hypotheses $n^{\circ} I, n^{\circ} 4$, $\mathrm{n}^{\circ} 5$, and $\mathrm{n}^{\circ} 6$.

Table 4. Regression results of the OS impacts on the CBs' profitability. 
As illustrated in Table (5), results distinguished that most governance variables have shown positive effects such as ACDIRi, ACDCAi, TYi, and LnAGi. However, given the probability attributed to them, only the effects related to TYi and LnAGi are significant at the I\% level. Whereas, LnTAi and LnINFi negatively affected the IBs' profitability at the significance level of $\mathrm{I} \%$. In conclusion, according to our prediction, only hypothesis $\mathrm{n}^{\circ} 3$ has been accepted in the case of IBs. Conversely, to what precedes in the theoretical part, we rejected hypotheses $n^{\circ} \mathrm{I}, \mathrm{n}^{\circ} 2, \mathrm{n}^{\circ} 4, \mathrm{n}^{\circ} 5$, and $\mathrm{n}^{\circ} 6$.

Table 5. Regression results of the OS impacts on the IBs' profitability.

\begin{tabular}{|c|c|c|c|c|c|c|c|}
\hline LnRti & Coefficient & Std. Err. & $\mathrm{Z}$ & $\mathrm{P}>|\mathrm{z}|$ & [95\% Conf. Interval] & Decision & \\
\hline ACDIRi & 0.0401876 & 0.058156 & 0.69 & 0.490 & -0.073796 & $0.154 I 7$ I3 & HI rejected \\
\hline ACDCAi & $0.036408 \mathrm{I}$ & $0.064 \mathrm{I} 34$ & 0.57 & 0.570 & -0.0892923 & 0.1621085 & $\mathrm{H} 2$ rejected \\
\hline TYi & 0.1196447 & 0.0410895 & $2.9 \mathrm{I}$ & $0.004^{x}$ & 0.0391107 & 0.2001787 & H3 accepted \\
\hline LnAGi & 0.2896096 & 0.0403766 & 7.17 & $0.000^{2}$ & 0.2104729 & 0.3687463 & H4 rejected \\
\hline LnTAi & -0.2646369 & 0.1374953 & -1.92 & $0.054^{\prime}$ & $-0.534 \mathrm{I} 226$ & 0.0048489 & H5 rejected \\
\hline$\overline{\text { LnINFi }}$ & $-0.449473 \mathrm{I}$ & 0.0328132 & -13.70 & $0.000^{2}$ & -0.5137858 & -0.3851604 & H6 rejected \\
\hline Constant & 2.9022 & 0.318793 & 9.10 & 0.000 & 2.277377 & 3.527023 & - \\
\hline
\end{tabular}

B. Impacts of the OS quality on the efficiency of conventional and Islamic banks

Based on the efficiency's specific results shown in Table (6), treatment of the impact of dependence between OS and CBs' efficiency reported that ACDIRc, LnAGc, and LnINFc generated positive and significant signs at the rate of the $\mathrm{I} \%$. Nevertheless, TYc and LnTAc showed negative and significant impacts at the level of I\%. In opposite, we recorded that ACDCAC revealed a positive but not significant impact on the CBs' efficiency. According to what is preconceived, we confirmed only hypothesis $n^{\circ} 6$. However, hypotheses $n^{\circ} \mathrm{I}, \mathrm{n}^{\circ} 2, \mathrm{n}^{\circ} 3, \mathrm{n}^{\circ} 4$, and $\mathrm{n}^{\circ} 5$ are not appropriate in the case of CBs.

Table 6. Regression results of the OS impacts on the CBs' efficiency.

\begin{tabular}{|c|c|c|c|c|c|c|c|}
\hline Etc & Coefficient & Std. Err. & Z & $\mathrm{P}>|\mathrm{z}|$ & \multicolumn{2}{|c|}{ [95\% Conf. Interval] } & Decision \\
\hline ACDIRc & $0.194206 \mathrm{I}$ & 0.056155 & 3.46 & $0.00 I^{2}$ & $0.084 \mathrm{I} 443$ & 0.3042679 & HI rejected \\
\hline ACDCAc & 0.0520437 & 0.0944604 & 0.55 & 0.582 & -0.1330954 & 0.2371827 & $\mathrm{H} 2$ rejected \\
\hline TYc & -0.1977136 & $0.05826 \mathrm{II}$ & -3.39 & $0.001^{2 x}$ & -0.3 I I9033 & -0.0835239 & H3 rejected \\
\hline LnAGc & 0.2191731 & 0.045672 & 4.80 & 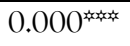 & 0.1296577 & 0.3086886 & H4 rejected \\
\hline LnTAc & -0.7279103 & 0.0988708 & -7.36 & 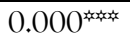 & -0.9216936 & $-0.534 \mathrm{I} 27 \mathrm{I}$ & H5 rejected \\
\hline LnINFc & 0.2770626 & 0.0310374 & 8.93 & 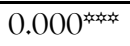 & 0.2162303 & 0.3378949 & H6 accepted \\
\hline Constant & -3.215325 & 0.3049575 & -10.54 & 0.000 & $-3.8 \mathrm{I} 303 \mathrm{I}$ & -2.61762 & - \\
\hline
\end{tabular}

Similarly, according to Table (7), the IBs' efficiency has been positively stimulated by the impact of IBs' OS. By way of clarification, ACDCAi, LnAGi, LnTAi, and LnINFi have significantly increased the effectiveness of IBs at a rate of I\%. Similarly, ACDIRi has had an influential impact on efficiency at the $10 \%$ level. On the contrary, we recorded that TYi affected the IBs' efficiency negatively and significantly at the level of $1 \%$. As pre-established, we confirmed the respective hypotheses $n^{\circ} 2$ $n^{\circ} 5$, and $n^{\circ} 6$ related to the Islamic banking model. Nevertheless, we ignored hypotheses $n^{\circ} I, n^{\circ} 3, n^{\circ} 4$, and $n^{\circ} 5$.

Table 7. Regression results of the OS impacts on the IBs' efficiency.

\begin{tabular}{|c|c|c|c|c|c|c|c|}
\hline Eti & Coefficient & Std. Err. & $\mathrm{Z}$ & $\mathrm{P}>|\mathrm{z}|$ & \multicolumn{2}{|c|}{$[95 \%$ Conf. Interval] } & Decision \\
\hline ACDIRi & 0.0015455 & 0.0009081 & 1.70 & 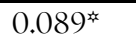 & -0.0002343 & 0.0033253 & HI rejected \\
\hline$\overline{\mathrm{ACDCAi}}$ & 0.0028715 & 0.0010394 & 2.76 & $0.006^{x}$ & 0.0008342 & 0.0049087 & H2 accepted \\
\hline TYi & -0.0002366 & $0.000597 \mathrm{I}$ & -0.40 & $0.002^{2}$ & -0.001407 & 0.0009337 & H3 rejected \\
\hline LnAGi & 0.0086876 & 0.0007524 & II.55 & 0.000 & 0.007213 & 0.0101622 & H4 rejected \\
\hline LnTAi & 0.0098982 & 0.0033608 & 2.95 & $0.003^{x+x}$ & 0.0033 III & 0.0164852 & H5 accepted \\
\hline LnINFi & 0.0029824 & 0.0006453 & 4.62 & 0.000 & 0.0017176 & $0.004247 \mathrm{I}$ & H6 accepted \\
\hline Constant & -0.0393684 & $0.00705 \mathrm{I}$ & -5.58 & 0.000 & -0.0531882 & -0.0255486 & - \\
\hline
\end{tabular}


C. Impacts of the OS quality on the liquidity of conventional and Islamic banks

Concerning the degree of OS impact on the CBs' liquidity, as noted in Table (8), the analysis of this model's specific coefficients showed that ACDIRc, ACDCAc, TYc, and LnINFc played a destructive role on liquidity at the significance level of I\%. Similarly, LnTAc has a negative impact on the process of producing liquidity, but not necessarily significant. However, only LnAGc improved significantly monetary resources with a $1 \%$ threshold. As expected, only the first assumption has been explicitly confirmed for the CBs' liquidity model. Contrary to what is planned, empirical results led us to reject hypotheses $\mathrm{n}^{\circ} 2$, $\mathrm{n}^{\circ} 3, \mathrm{n}^{\circ} 4, \mathrm{n}^{\circ} 5$, and $\mathrm{n}^{\circ} 6$.

Table 8. Regression results of the OS impacts on the CBs' liquidity.

\begin{tabular}{|c|c|c|c|c|c|c|c|}
\hline Ltc & Coefficient & Std. Err. & $\mathrm{Z}$ & $\mathrm{P}>|z|$ & \multicolumn{2}{|c|}{ [95\% Conf. Interval] } & Decision \\
\hline$\overline{A C D I R c}$ & -0.0242592 & 0.0113422 & -2.14 & $0.032^{\text {th }}$ & -0.0464896 & -0.0020289 & HI accepted \\
\hline ACDCAc & -0.0595978 & 0.0129346 & $-4.6 \mathrm{I}$ & $0.000^{\prime}$ & -0.0849492 & -0.0342464 & H2 rejected \\
\hline TYc & -0.0229816 & 0.0102339 & -2.25 & $0.025^{\infty}$ & $\begin{array}{l}-0.0430398 \\
\end{array}$ & -0.0029235 & H3 rejected \\
\hline LnAGc & 0.0408646 & 0.0101021 & 4.05 & $0.000^{\text {and }}$ & 0.0210647 & 0.0606644 & H4 rejected \\
\hline LnTAc & -0.025676 & 0.0191403 & $\begin{array}{l}-1.34 \\
\end{array}$ & 0.108 & -0.0631903 & 0.0118383 & H5 rejected \\
\hline LnINFc & -0.0677669 & 0.0077436 & -8.75 & 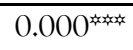 & -.082944 & -.0525898 & H6 rejected \\
\hline Constant & 0.7455678 & 0.0641508 & 11.62 & 0.000 & 0.6198345 & $0.87 \mathrm{I} 30 \mathrm{I}$ & - \\
\hline
\end{tabular}

Furthermore, referring to the Table (9), the estimated liquidity model gave rise to coefficients with positive and significant signs at the I\% level, representing stimulators for the IBs' liquidity as well as ACDCAi and LnTAi. Otherwise, ACDIRi, TYi, LnAGi, and LnINFi affected available liquidity generated by the operating cycle within IBs significantly at the $\mathrm{I} \%$ threshold. Taking into consideration the decision rules, we accepted hypotheses $n^{\circ} \mathrm{I}, \mathrm{n}^{\circ} 2, \mathrm{n}^{\circ} 4$, and $\mathrm{n}^{\circ} 5$, which have been validated for the Islamic financing system. Also, contrary to our original proposals, we rejected hypotheses $n^{\circ} 3$, and $n^{\circ} 6$.

Table 9. Regression results of the OS impacts on the IBs' liquidity.

\begin{tabular}{|c|c|c|c|c|c|c|c|}
\hline Lti & Coefficient & Std. Err. & $\mathrm{Z}$ & $\mathrm{P}>|\mathrm{z}|$ & \multicolumn{2}{|c|}{ [95\% Conf. Interval] } & Decision \\
\hline ACDIRi & -0.0290847 & 0.0104638 & -2.78 & $0.005^{x}$ & -0.0495933 & -0.008576 & HI accepted \\
\hline$\overline{\mathrm{ACDCAi}}$ & 0.0483708 & 0.0122229 & 3.96 & 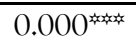 & $0.0244 \mathrm{I} 44$ & 0.0723273 & H2 accepted \\
\hline TYi & -0.0476289 & 0.0088589 & -5.38 & $0.000^{2 x+x+x}$ & $-0.064992 \mathrm{I}$ & -0.0302657 & H3 rejected \\
\hline LnAGi & -0.045777 & 0.0087286 & -5.24 & 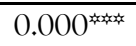 & -0.0628847 & -.0286692 & H4 accepted \\
\hline LnTAi & 0.3048453 & 0.0212675 & $\mathrm{I} 4.33$ & $0.000^{2}$ & 0.2631619 & 0.3465288 & H5 accepted \\
\hline LnINFi & -0.0513763 & $0.00665 \mathrm{I}$ & -7.72 & 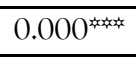 & $-0.0644 \mathrm{I} 2$ & -0.0383406 & H6 rejected \\
\hline Constant & 0.16438 II & 0.0608899 & 2.70 & 0.007 & $0.045039 \mathrm{I}$ & 0.283723 & - \\
\hline
\end{tabular}

D. Impacts of the OS quality on the solvency of conventional and Islamic banks

In the same interpretation line, based on the results in Table (I0), the coefficients associated with the OS revealed that ACDIRc, LnAGc and LnTAc traced considerable signs allowing to protect the level of the CBs' solvency at the respective significance thresholds of $1 \%, 5 \%$ and $\mathrm{I} \%$. Conversely, LnINFc determined the CBs' solvency at the level of $\mathrm{I} \%$. Similarly, other variables such as ACDCAc and TYc showed a worrisome impact on the ability of continuing solvency in CBs, but these impacts are not significant. In accordance with previous studies, we rejected only hypothesis $n^{\circ} 5$. Unlike previous studies, we ignored hypotheses $n^{\circ} 1, n^{\circ} 2, n^{\circ} 3, n^{\circ} 4$, and $n^{\circ} 6$ in the case of the CBs.

Table 10. Regression results of the OS impacts on CBs' solvency.

\begin{tabular}{|c|c|c|c|c|c|c|c|}
\hline LnStc & Coefficient & Std. Err. & $\bar{Z}$ & $\mathrm{P}>|z|$ & \multicolumn{2}{|c|}{ [95\% Conf. Interval] } & Decision \\
\hline ACDIRc & 0.1139856 & 0.0247266 & $4.6 \mathrm{I}$ & $0.001^{x+4 x}$ & 0.162449 & 0.0655223 & HI rejected \\
\hline ACDCAC & -0.00403 I I & 0.0255813 & -0.16 & 0.875 & -0.0541696 & 0.0461075 & $\mathrm{H} 2$ rejected \\
\hline TYc & -0.0142717 & 0.0137713 & -1.04 & 0.300 & -0.0412629 & 0.0127196 & H3 rejected \\
\hline LnAGc & $0.039466 \mathrm{I}$ & 0.0189036 & 2.09 & $0.037^{\text {㖣 }}$ & 0.0024157 & $0.0765 \mathrm{I} 64$ & H4 rejected \\
\hline LnTAc & 0.0738973 & 0.0263525 & 2.80 & 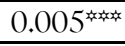 & 0.0222474 & 0.1255472 & H5 accepted \\
\hline LnINFc & -0.107604 & 0.0135956 & $-7.9 \mathrm{I}$ & $0.000^{\text {本金卒 }}$ & $-0.13425 \mathrm{I}$ & -0.080957 & H6 rejected \\
\hline Constant & -0.1667908 & 0.0838698 & -1.99 & 0.047 & -0.3311726 & $-0.002409 \mathrm{I}$ & - \\
\hline
\end{tabular}


Through the estimation of the IBs' solvency model, we found that ACDCAi and LnTAi protected its solvency significantly at the I\% threshold. However, other control variables such as TYi, LnAGi, and LnINFi reported prodigious and significant negative impacts at a rate of I\%. Symmetrically, ACDIRi recorded a negative and insignificant impact on the IBs' solvency. Therefore, from the findings recorded in Table II, we validated hypotheses $n^{\circ} 2, n^{\circ} 4$, and $n^{\circ} 5$. In the opposite, we rejected hypotheses $n^{\circ} \mathrm{I}, \mathrm{n}^{\circ} 3$, and $\mathrm{n}^{\circ} 6$ for the model corresponding to the IBs' solvency.

Table II. Regression results of the OS impacts on the IBs' solvency

\begin{tabular}{|c|c|c|c|c|c|c|c|}
\hline LnSti & Coefficient & Std. Err. & $\mathrm{Z}$ & $\mathrm{P}>|\mathrm{z}|$ & \multicolumn{2}{|c|}{ [95\% Conf. Interval] } & Decision \\
\hline ACDIRi & -0.0773454 & 0.0733139 & I.05 & $0.29 \mathrm{I}$ & -0.0663472 & 0.221038 & HIrejected \\
\hline ACDCAi & 0.2768014 & $0.07465 \mathrm{I}$ & $3.7 \mathrm{I}$ & $0.000^{2}$ & 0.1304882 & $0.423 I$ I 46 & H2 accepted \\
\hline TYi & -0.12 III7 & 0.0458903 & -2.64 & $0.008^{x}$ & -.2110604 & $-.03 I I 736$ & H3 rejected \\
\hline LnAGi & -0.1772519 & 0.0450398 & -3.94 & 0.000 & -.2655283 & -.0889756 & H4 accepted \\
\hline LnTAi & I.I2I58I & 0.1960655 & 5.72 & $0.000^{x}$ & 0.7372996 & I.505862 & H5 accepted \\
\hline LnINFi & -0.2963016 & 0.0442308 & -6.70 & $0.000^{2}$ & -0.3829923 & $-0.2096 \mathrm{II}$ & H6 rejected \\
\hline Constant & -1.766628 & 0.3945176 & -4.48 & 0.000 & -2.539868 & -0.9933877 & - \\
\hline
\end{tabular}

4.2.2 Analogical study between the significant impacts of the ownership structure quality on the financial performance measures From the foregoing, the mono-analysis already carried out has shown an ambiguity of confirmation or assertion of the hypotheses from a single determinant of the FP. First, not all OS determinants of the two bank types revealed significant effects on the FP measures. Besides, not all the OS determinants of each bank type recorded the same signs. To overcome the problem of inconsistency of the non-significant impacts, we were limited to the variables that revealed significant signs. Then, the resolution of the incompatibility of the signs led us to establish a state of reconciliation between the significant effects of the OS determinants specific to each bank type. To better appreciate the difference in OS effects on the FP of each bank type, we compared the individual effects of each OS determinant on the same FP measure for each bank type. Table I2 illustrated the reconciliation results specific to CBs with their Islamic counterparts.

Table 12. Summary of the significant impacts of the OS determinants on FP measurements between conventional and Islamic banks.

\begin{tabular}{cllll}
\hline & CB & & IB \\
\hline Model & Positive impact & Negative impact & Positive impact & Negative impact \\
\hline Rt & ACDIRc & $/$ & $/$ & $/$ \\
& ACDCAc & & & \\
\hline Et & ACDIRc & $/$ & ACDIRi & $/$ \\
& & & ACDCAi & \\
\hline Lt & $/$ & ACDIRc & ACDCAi & ACDIRi \\
& & ACDCAc & & \\
\hline St & ACDIRc & $/$ & ACDCAi & $/$ \\
\hline similar impacts & 4 & 2 & 4 & I \\
\hline
\end{tabular}

From Table (I2), we noted that the exclusion of non-significant impacts and the aggregation of significant impacts clarifies and simplifies the vision. On the one hand, the approach between the impacts on FP has shown that the IBs' OS has improved its efficiency and solvency, but this ownership model has affected some of their efficiency. On the other hand, the CBs' OS has improved their profitability, their efficiency, and their solvency; however, the ownership characteristics within the CBs can deteriorate their liquidity. In conclusion, the OS of the two bank types had a positive impact on their FP despite affecting some of its determinants.

\section{Conclusion}

We have noticed that our empirical results are not conclusive in the case of two models of banks, we pointed out that the OS quality in the banking environment represents a two-way destiny that does not have a decisive impact on FP. We have estimated that CEO shareholding improves banking performance. Also, the board's chairman shareholding has normally contributed to 
improving the FP of conventional and Islamic banks. However, the reality has revealed mixed results, all depend on the performance measure, and the degree of partial impact varies from one OS determinant to another and from one performance parameter to another for the same control variable. Besides, the results vary from one performance measure to another for the same OS characteristic, depending on the study context, the accounting standards applied and the governance approach followed.

Moreover, according to the theory of social exchanges, power is defined as dependence and interdependence between actors (Emerson, 1962). The power to manage, control, decide and rectify is based on the contingency of the actors, their behavioral states (balanced, opportunistic or satisfied) and the behavioral reactions of the stakeholders in general. A better quality of governance is a deterrent against manipulation and overtaking by shareholders and managers in particular. Nevertheless, a hard governance system is also an inevitable indicator of growth of opportunistic behavior, which is translated into excessive risk-taking, the development of non-productive or toxic assets, and overvaluation of loan loss provisions. FP is not an objective, but rather a management factor of results, manipulation and especially a reason for the birth of opportunistic behaviors.

For these reasons, we discovered a new method of grouping the heterogeneous and detailed impacts of the OS on the FP through which we argued that the OS has revealed a driving impact on FP in each bank type. The development of new governance aspects of shareholder and management shareholding aimed at driving the shareholding policy of banks has become a necessity. Global unification of shareholder auditing standards, while respecting the particularities of each banking model, facilitates the supervision of shareholders and managers regardless of the bank type.

\section{References}

Alharthi, M. (2016). The determinants of efficiency, profitability, and stability in the banking sector: a comparative study of Islamic, conventional and socially responsible banks. Ph.D. thesis. University of Plymouth.

Al-Rassas, A.H., \& Kamardin, H. (2016). Earnings quality and audit attributes in high concentrated ownership market. Corporate Governance, I6(2), 377-399.

Aminul, A., Niki, L., Djoko, S., \& Erna, S. (2018). Audit committee characteristics and audit-earnings quality: empirical evidence of the company with concentrated ownership. Review of Integrative Business and Economics Research. 7(I), I8-33.

Badreldin, A.M. (2009). Measuring the performance of Islamic banks by adapting conventional ratios. German university of Cairo. Working paper No. I6.

Beltratti, A., \& Stulz, R.M. (20I2). The credit crisis around the globe: why did some banks perform better? Journal of Financial Economics, IO5(I), I-I7.

Bhagat, S., \& Black, B. (2002). The non-correlation between board independence and long-term firm performance. Journal of Corporation Law, 27(2), 23I-274.

Batir, T. E., Volkman, D. A., \& Gungor, B. (2017). Determinants of bank efficiency in Turkey: Participation banks versus conventional banks. Borsa Istanbul Review, I7(2), 86-96.

Bilal, M., \& Abbas, S. (2015). Comparison of Islamic banking and conventional banking: an empirical review. International Journal of Management and Organizational Studies, 4(I), 39-43.

Bozec, Y., \& Bozec, R. (2007). Ownership concentration and corporate governance practice: substitution expropriation effects. Canadian Journal of Administrative Science, 24(3), 182-195.

Caglayan, E., \& Sak, N. (20I0). The determinants of capital structure: evidence from the Turkish banks. Journal of Money, Investment and Banking, 15, 57-65.

Carcello, J.V., Hermanson, D.R., \& Ye, Z.S. (20II). Corporate governance research in accounting and auditing: insights, practice implications, and future research directions. Journal of Practice and Theory, 30(3), I-3I.

Carter, R.B., \& Stover, R.D. (I99I). Management ownership and firm compensation policy: evidence from converting savings and loan associations. Financial Management, 20(4), 80-90.

Chong, B.S., \& Liu, M.H. (2009). Islamic banking: interest-free or interest-based? Pacific-Basin Finance Journal, I7, (I) I25$\mathrm{I} 44$.

Cornett, M.M., McNutt, J.J., \& Tehranian, H. (2009). Corporate governance and earnings management at large US bank holding companies. Journal of Corporate Finance, I5(4), 412-430.

Demsetz, H., \& Lehn, K. (I985). The structure of corporate ownership: causes and consequences. Journal of Political Economy, 93(6), I II5-II77.

Dhillon, A., \& Rossetto, S. (20I5). Ownership structure, voting, and risk. The Review of Financial Studies, $28(2), 52 \mathrm{I}-560$.

Emerson, R. (1962). Power-dependence relations. American Sociological Review, 27( I), 3I-4I.

Fahad, N.U. (20I4). An econometric analysis on the financial performance of commercial banks in Bangladesh: a comparative study. Journal of Business Studies, 8, 33-50. 
Fahlenbrach, R., \& Stulz, R.M. (20I I). Bank CEO incentives and the credit crisis. Journal of Financial Economics, 99, I I-26.

Flamini, V., McDonald, C., \& Schumacher, L. (2009). The determinants of commercial bank profitability in sub-saharan Africa. Working paper, No. 09/I5. International monetary fund.

Gebba, T.R., \& Aboelmaged, M.G. (2016). Corporate governance of UAE financial institutions: a comparative study between conventional and Islamic banks. Journal of Applied Finance and Banking, 6(5), I 19-160.

Grigorian, D., \& Manole, V. (2002). Determinants of commercial bank performance in transition: an application of data envelopment analysis. World bank policy research, Working paper No. 2850.

Gropp, R., \& Heider, F. (2010). The determinants of bank capital structure. Review of Finance, I4(4), 587-622.

Gul, S., Irshad, F., \& Zaman, K. (20II). Factors affecting bank profitability in Pakistan. The Romanian Economic Journal, I4(39), 6I-87.

Gurbuz, A.O., Aybars, A., \& Kutlu, O. (2010). Corporate governance and financial performance with a perspective on institutional ownership: empirical evidence from Turkey. JAMAR, 8(2), 22-37.

Hussein, H.A., \& Charif, H. (20II). Multiple approaches in performance assessment of UAE commercial banks. International Journal of Islamic and Middle Eastern Finance and Management, 4(I), 74-82.

Iannotta, G., Nocera, G., \& Sironi, A. (2007). Ownership structure, risk, and performance in the European banking industry. Journal of Banking and Finance, 3I(7), 2127-2I47.

Iqbal, J., Strobl, S., \& Vahamaa, S. (20I5). Corporate governance and the systemic risk of financial institutions. Journal of Economics and Business, 82(C), 42-61.

Jemric, I., \& Vujcic, B. (2002). Efficiency of banks in Croatia: a DEA approach. Comparative Economic Studies, 44(2-3), I69193.

Jensen, M.C., \& Meckling, W.H. (I976). Theory of the firm: managerial behavior, agency costs, and ownership structure. Journal of Financial Economics, 3(4), 305-360.

Kallamu, B.S. (2016). Ownership structure, independent directors and firm performance. E3 Journal of Business Management and Economics, $7(\mathrm{I}), \mathrm{I9}-28$.

Kim, P.K., \& Rasiah, D. (2010). Relationship between corporate governance and bank performance in Malaysia during the pre and post Asian financial crisis. European Journal of Economics, Finance and Administrative Sciences, 2I(I), $39-63$.

Kraft, E., \& Tirtiroglu, D. (1998). Bank efficiency in Croatia: a stochastic-frontier analysis. Journal of Comparative Economics, $26(2), 282-300$.

Lang, L., \& So, S. (2002). Bank ownership structure and economic performance. SSRN, Working paper.

Macey, J.R., \& O'Hara, M. (2003). The corporate governance of banks. Federal Reserve Bank of New York, Economic Policy Review, $9(\mathrm{I}), 9 \mathrm{I}-\mathrm{IO} 7$.

Manthos, D.D., \& Nikolaos, I.P. (2009). Determinants of bank efficiency: evidence from a semi-parametric methodology. Managerial Finance, 35(3), 260-275.

Needles, B.E., Turel, J.A., Sengur, E.D., \& Asli, T. (2012). Corporate governance in Turkey: issues and practices of highperformance companies. Journal of Accounting and Management Information Systems, II(4), 5I0-53I.

Onali, E., Galiakhmetova, R., Molyneux, P., \& Torluccio, G. (20I6). CEO power, government monitoring, and bank dividends. Journal of Financial Intermediation, 27(C), 89-II7.

Ozer, B., and Yamak, S., (2000). The role of market control on the relation between ownership and performance: evidence from Turkish market. EFMA, Lugano meetings. Available at: http://ssrn.com/absract=268089.

Rashwan, M.H., \& Ehab, H. (2016). Comparative efficiency study between Islamic and traditional banks. Journal of Finance and Economics, 4(3), 74-85.

Rowe, W., Shi, W., \& Wang, C. (20II). Board governance and performance of Chinese banks. Banks and Bank System, 6(I), 26-40.

Saeed, M.S. (20I4). Bank-related, industry-related and macroeconomic factors affecting bank profitability: a case of the United Kingdom. Research Journal of Finance and Accounting, 5(2), 42-50.

Samad, A. (2004a). Performance of interest free Islamic banks vs interest-based conventional banks of Bahrain. IIUM Journal of Economics and Management, I2(2), I-25.

Sufian, F., \& Noor Mohamad Noor, M. A. (2012). Determinants of bank performance in a developing economy: Does bank origins matters?. Global Business Review, I3(I), I-23.

Shamsher, M., Hassan, T., \& Bader, M.K.I. (2008). Efficiency of conventional versus Islamic banks: international evidence using the stochastic frontier approach (SFA). Journal of Islamic Economics, Banking and Finance, 4(2), I07-I30.

Shleifer, A., \& Vishny, R. (1997). A survey of corporate governance. Journal of Finance, 52(2), 737-783.

Tandelilin, E., Kaaro, H., Mahadwartha, P.A., \& Supriyatna, S. (2007). Corporate governance, risk management and bank performance: does type of ownership matter? EADN working paper No. 34. 
Thu, N.T.H., Hung, P.M., \& Anh, N.T.L. (2016). An empirical study of corporate governance and banks' performance in Vietnamese commercial banks. SIU Journal of Management, 6(2), 87-I I4.

\section{Copyrights}

Copyright for this article is retained by the author(s), with first publication rights granted to the journal. This is an open-access article distributed under the terms and conditions of the Creative Commons Attribution license (http://creativecommons.org/licenses/by/4.0/). 